\title{
Glycine encephalopathy
}

INSERM

\section{Source}

INSERM. (1999). Orphanet: an online rare disease and orphan drug data base. Glycine encephalopathy. ORPHA:407

Glycine encephalopathy (GE) is an inborn error of glycine metabolism characterized by accumulation of glycine in body fluids and tissues, including the brain, resulting in neurometabolic symptoms of variable severity. 